\title{
New data on braconid wasps (Hymenoptera: Braconidae: Cheloninae, Opiinae, Rogadinae) of South-Eastern Iran
}

\author{
Seyed Massoud Madjdzadeh*(1), Mohammad Purrezaali(2), Sana Dolati ${ }^{(3)} \&$ Taghi \\ Ghassemi-Khademi ${ }^{(4)}$
}

(1) Department of Biology, Faculty of Sciences, Shahid Bahonar University of Kerman, Kerman, Iran (Email:madjdzadeh@uk.ac.ir)

${ }^{(2)}$ Young Researchers and Elite Club, Kerman Branch Islamic Azad University, Kerman, Iran (E-mail: mohammad.porrezaali@gmail.com)

${ }^{(3)}$ Department of Agricultural Entomology, Faculty of Agriculture, Tarbiat Modares University, Tehran, Iran (E-mail: sana.dolatii@gmail.com)

${ }^{(4)}$ Department of Biology, Faculty of Sciences, University of Shiraz, Shiraz, Iran (E-mail: ghasemi.taghi@gmail.com)

* Corresponding author: Seyed Massoud Madjdzadeh E-mail: madjdzadeh@uk.ac.ir

Reçu le 20 octobre 2020, accepté le 05 décembre 2020

The fauna of Braconidae (Hymenoptera: Ichneumonoidea: Cheloninae, Opiinae, Rogadinae) was studied in different habitats of Kerman province, southeastern Iran. The specimens were collected using sweep net, Malaise traps and light trap during 2013 to 2018. Three subfamilies: Cheloninae, Opiinae and Rogadinae were identified in the present study. A total of 11 species belonging to six genera were identified. Among identified sample, a single species, Opius (Cryptonastes) ficedus Papp, 1979 (Opiinae) is reported for the first time from Iran.

Key words: Iran, Hymenoptera, Braconidae, distribution, faunistics, new record.

La faune des Braconidae ((Hymenoptera: Ichneumonoidea: Cheloninae, Opiinae, Rogadinae) a été étudiée dans différents habitats de la province de Kerman, Iran. Les specimens ont été collectés par filet, piège Malaise et piège lumineux entre 2013 et 2018. Trois sous familles, Cheloninae, Opiinae and Rogadinae, ont été identifiées dans la présente étude. Un total de 11 espèces appartenant à six genres ont été identifiées. Parmi les échantillons identifiés, une seule espèce, Opius (Cryptonastes) ficedus Papp, 1979 (Opiinae) est rapportée pour la première fois en Iran.

Mots clés : Iran, Hymenoptera, Braconidae, distribution faunistique, nouvelle espèce.

\section{INTRODUCTION}

Braconidae (Hymenoptera: Ichneumonoidea) is the second largest family of Hymenoptera, with more than 20.000 described species, in more than 1000 genera and 46 subfamilies, worldwide (Yu et al., 2016). They play major ecological roles in the regulation of other insect groups. They have been used in the biological control of agricultural and forest pests (Coronado et al., 2004).

The subfamily Cheloninae Foerster is a large subfamily with about 1300 described species worldwide (Yu et al., 2016). Members of this subfamily are solitary egg-larval koinobiont endoparasitoids on various Lepidoptera, especially Pyraloidea and Tortricoidea (Shaw \& Huddleston, 1991). The subfamily Opiinae is considered as one of the largest groups of Braconidae with more than 2063 valid species in 39 genera ( $\mathrm{Li}$ et al., 2013; Yu et al., 2016). The species of this subfamily are solitary koinobiont endoparasitoids of larvae of cyclorraphous Diptera (Wharton, 1997). The hosts are known for only around 300 species, mostly within Agromyzidae, Anthomyiidae, Drosophilidae, Ephydridae, Psilidae, Scatophagidae and Tephritidae (Fischer 1971a,b, 1972, 1977, 1987; Shaw \& Huddleston, 1991). Rogadinae is a widespread subfamily of koinobiont endoparasitoids of Lepidoptera (Shaw, 1997). All Rogadinae induce the hardening of the host larva before 
pupation, producing a "mummy" which conceals the parasitoid pupa (Shaw et al. 1997). More than 1159 species of Rogadinae have been described in 58 genera, which most of them are distributed to northern Europe, Asia, and North America (Yu et al., 2016).

Recently some contributions were made on the Iranian fauna of Cheloninae (Fallahzadeh \& Saghaei, 2010; Lashkari-Bod et al., 2011; Ameri et al., 2012; Farahani et al., 2012, 2013, 2014; Derafshan et al., 2017), Opiinae (Lashkari-Bod et al., 2011; Ameri et al., 2014; Khajeh et al., 2014, Ranjbar et al., 2016; PerisFelipo et al., 2018; Safahani et al., 2018, Dolati et al., 2018, 2019) and Rogadinae (Telenga, 1941; Hedwig, 1957; Shenefelt, 1975; Lashkari-Bod et al., 2011; Farahani et al., 2015). The objective of this study (being part of our ongoing research on the braconid fauna of Iran) is to improve our knowledge of the family Braconidae in Iran.

\section{MATERIAL and METHODS}

The braconid specimens were collected using a standard sweep net, Malaise traps and light traps at different habitats (farms and orchards) located in Kerman province, southeastern Iran during 2013-2018 (Figure 1). The specimens were collected from the traps and sorted weekly. Among collected material, 94 specimens belonging to three subfamilies: Cheloninae, Opiinae and Rogadinae were identified. The collected specimens were subsequently dried and mounted on cards using AXA method (van Achterberg, 2009). The external morphology of specimens was studied using NIKON SMZ800 stereomicroscope. Nomenclature and distributional data are mainly from $\mathrm{Yu}$ et al. (2016). The voucher specimens were deposited in the Insect Collection of the Zoological Museum of Shahid Bahonar University of Kerman, Kerman, Iran (ZMSBUK). 


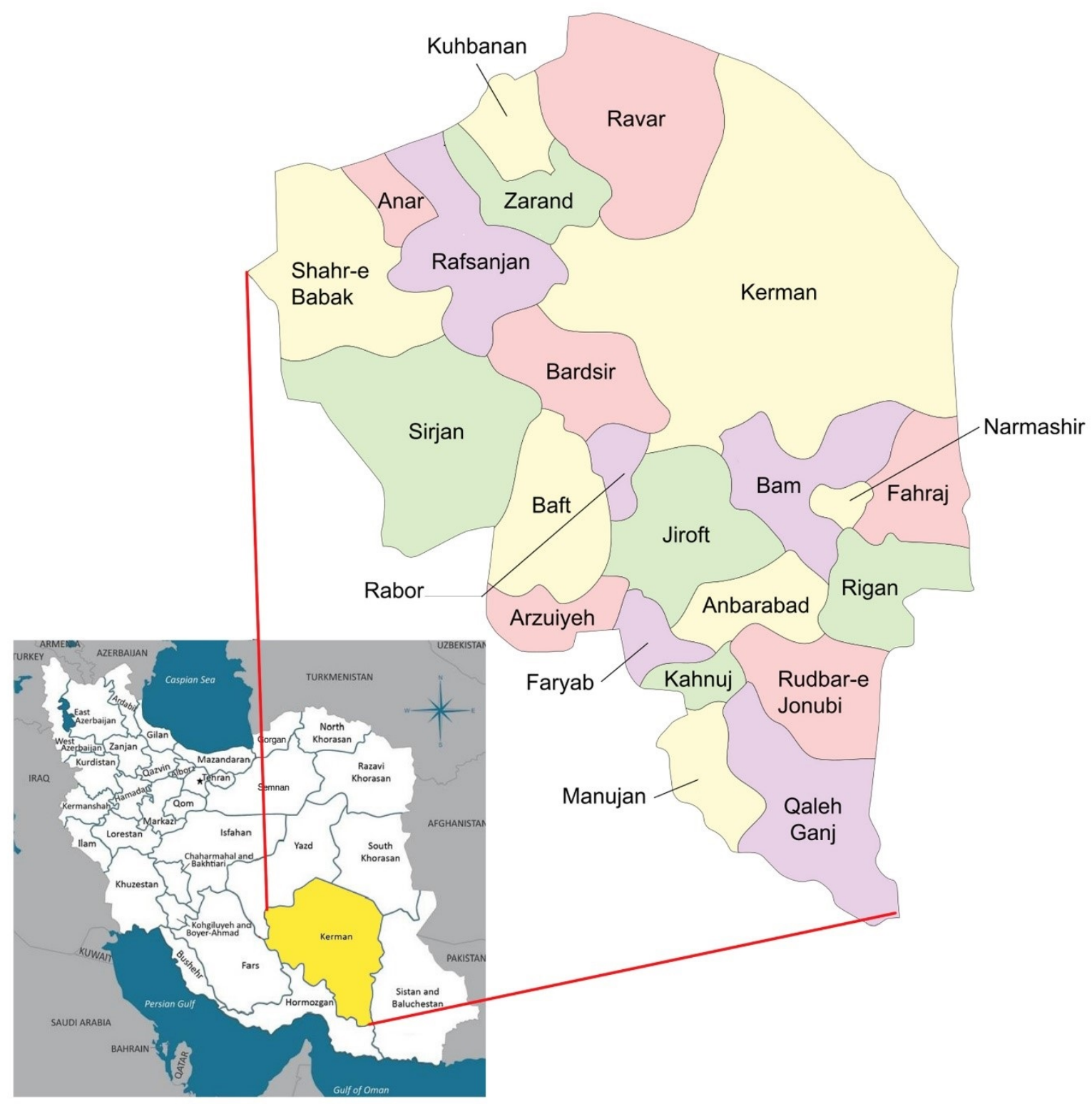

Figure 1: Geographic map of Kerman province

\section{RESULTS}

A total of 11 species belonging to six genera of the 3 subfamilies studied were identified. Among the collected material the species Opius (Cryptonastes) ficedus Papp, 1979 (Opiinae) is a new record for the fauna of Iran. m. a. s. 1. refers to 'meters above sea level'.

\section{Subfamily Cheloninae Förster 1862}

\section{Tribe Chelonini Förster 1862}

\section{Chelonus (Chelonus) annulipes Wesmael 1835}

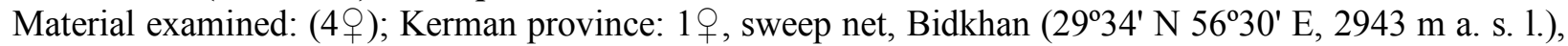
01.viii.2014; 1 \%, sweep net, Negar, (29 53' N 56 46' E, 2096 m a. s. 1.), 21. viii.2014; leg: F. Abdolalizadeh;

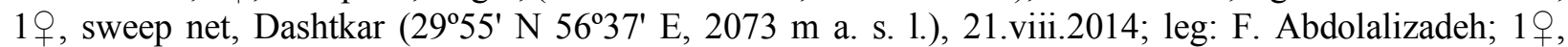
Malaise trap, Sirch ( $30^{\circ} 11^{\prime}$ N $57^{\circ} 34$ E'), 25.v.2013, leg.: Sh. Mohebban.

Distribution in Iran: Alborz, Tehran, Guilan, Qazvin, Semnan provinces (Farahani et al., 2016). General distribution: Nearctic, Oriental and Palaearctic.

\section{Chelonus (Chelonus) oculator (Fabricius 1775)}




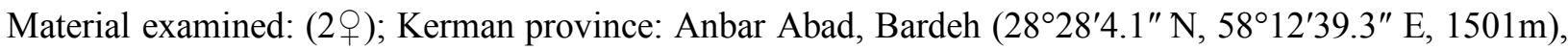
05-23.v.2017, 19, and 21.iv-05.v.2017, 1 , Malaise trap, Leg.: M. Purrezaali

Distribution in Iran: Lorestan, Alborz, Tehran and Qazvin provinces (Farahani et al., 2016).

General distribution: Palaearctic.

Tribe Phanerotomini Baker, 1926

3. Phanerotoma (Phanerotoma) leucobasis Kriechbaumer 1894

Material examined: (2+); Kerman province: Jiroft, Dalfard $\left(29^{\circ} 00^{\prime} 36^{\prime \prime} \mathrm{N}, 57^{\circ} 36^{\prime} 39.1^{\prime \prime} \mathrm{E}, 2232 \mathrm{~m}\right)$, 17.vii-

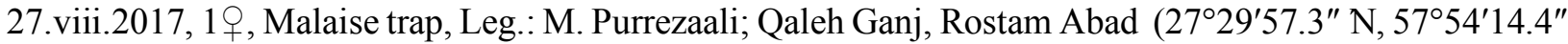
E, 387m), 14.iv.2018, 19, light trap, Leg.: M. Ehsani.

Distribution in Iran: Sistan and Baluchestan and Isfahan provinces (Farahani et al., 2016).

General distribution: Afrotropical, Nearctic and Palaearctic.

\section{Phanerotoma (Bracotritoma) permixtellae Fischer 1968}

Material examined: (1ㅇ); Kerman province: Dehbakri, Marghak, Bidkhun $\left(29^{\circ} 07^{\prime} 22.6^{\prime \prime} \mathrm{N}, 57^{\circ} 52^{\prime} 56.8^{\prime \prime} \mathrm{E}\right.$, 2220m), 04-16.vii.2017, 1ㅇ, Malaise trap, Leg.: M. Purrezaali.

Distribution in Iran: West Azarbaijan, Hormozgan and Golestan provinces (Farahani et al., 2016).

General distribution: Greece, Iran and Syria.

Subfamily Opiinae

\section{Opius (Cryptonastes) ficedus Papp 1979}

Material examined: (2+); Kerman province: Bam, Hemat Abad $\left(29^{\circ} 08^{\prime} 19.6^{\prime \prime} \mathrm{N}, 57^{\circ} 58^{\prime} 05.1^{\prime \prime} \mathrm{E}, 1673 \mathrm{~m}\right)$, 13-31.v.2017, 1으, and 31.v-04.vii. 2017, 1우, Malaise trap, Leg.: M. Purrezaali.

Distribution in Iran: Kerman province (current study). New record from Iran.

General distribution: Poland, Slovakia.

\section{Phaedrotoma exigua (Wesmael 1835)}

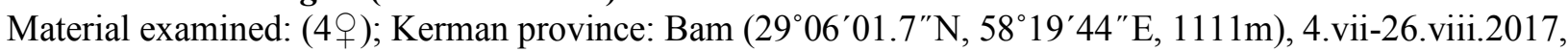
1 9 , 05-31.v.2017, 19 , 31.v-04.vii.2017, 2 , Malaise trap, Leg.: M. Purrezaali.

Distribution in Iran: Tehran, Lorestan and Sistan and Baluchestan provinces (Farahani et al., 2016).

General distribution: Afrotropical, Oriental and Palaearctic.

\section{Phaedrotoma pulchriceps (Szépligeti 1898)}

Material examined: (4ㅇ); Kerman province: Bam $\left(29^{\circ} 06^{\prime} 01.7^{\prime \prime} \mathrm{N}, 58^{\circ} 19^{\prime} 44^{\prime \prime} \mathrm{E}, 1111 \mathrm{~m}\right)$, 4.vii-26.viii.2017, 1 울 and 31.v-04.vii.2017, 1 , Malaise trap, Leg.: M. Purrezaali; Bam, Hemat Abad (29 08'19.6" N, 5758'05.1"E, 1673m), 31.v-04.vii. 2017, 2 + , Malaise trap, Leg.: M. Purrezaali.

Distribution in Iran: Guilan and East Azarbaijan provinces (Farahani et al., 2016).

General distribution: Nearctic, Oriental and Palaearctic.

\section{Xynobius rudis (Wesmael 1835)}

Material examined: (3ㅇ); Kerman province: Manujan $\left(27^{\circ} 29^{\prime} 53.1^{\prime \prime} \mathrm{N}, 57^{\circ} 33^{\prime} 43.4^{\prime \prime} \mathrm{E}, 358 \mathrm{~m}\right)$, 07.iv05.v.2017, 1옹 Malaise trap, Leg.: M. Purrezaali; Manujan, Chah Nasri $\left(27^{\circ} 31^{\prime} 14.6^{\prime \prime} \mathrm{N}, 57^{\circ} 33^{\prime} 51.5^{\prime \prime} \mathrm{E}\right.$, 384m), 20.iv-05.v.2017, 19, Malaise trap, Leg.: M. Purrezaali; Qaleh Ganj, Rostam Abad (27²9'57.3" N, 5754'14.4" E, 387m), 14.iv.2018, 19, light trap, Leg.: M. Ehsani.

Distribution in Iran: Kermanshah and Sistan and Baluchestan provinces (Farahani et al., 2016).

General distribution: Nearctic and Palaearctic.

\section{Subfamily Rogadinae Förster 1862}

Tribe Aleiodini Muesebeck 1928

\section{Aleiodes (Aleiodes) bicolor (Spinola 1808)}

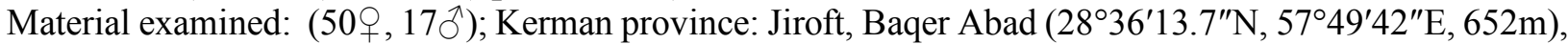
20.iv-13.v.2017, 1 ㅇ and 13-23.v.2017, 2을 Malaise trap, Leg.: M. Purrezaali; Manujan, Chah Nasri $\left(27^{\circ} 31^{\prime} 14.6^{\prime \prime} \mathrm{N}, 5^{\circ} 33^{\prime} 51.5^{\prime \prime} \mathrm{E}, 384 \mathrm{~m}\right), 10 . i v-05 . v .2017,3$ ㅇ and 05-22.v.2017, 1 , Malaise trap, Leg.: M.

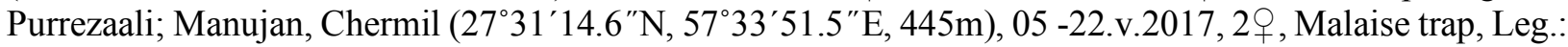

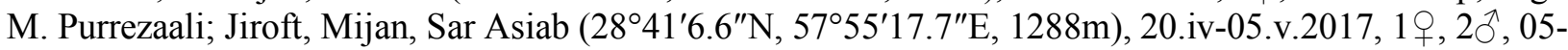

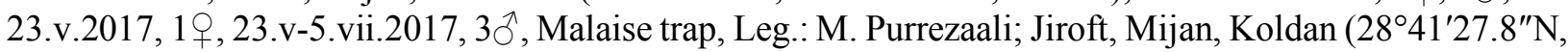

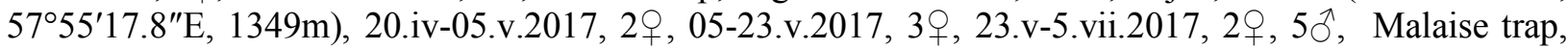
Leg.: M. Purrezaali; Anbar Abad, Bardeh (28 $28^{\prime} 4.1^{\prime \prime} \mathrm{N}, 58^{\circ} 12^{\prime} 39.3^{\prime \prime}$ E, 1501m), 21.iv-23.v.2017, 1 q , 05-

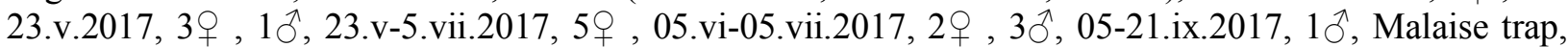

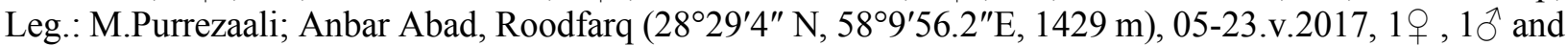


04.vi-5.vii.2017, 8 ㅇ , 1 ${ }^{\dagger}$, Malaise trap, Leg.: M.Purrezaali; Dehbakri, Marghak, Bidkhun $\left(29^{\circ} 07^{\prime} 22.6^{\prime \prime}\right.$ N, 57 52'56.8" E, 2220m), 22.v-04.vii.2017, 2 9 , Malaise trap, Leg.: M. Purrezaali; Bam $\left(29^{\circ} 06^{\prime} 01.7^{\prime \prime}\right.$ N, 58 19'44" E, 1111m), 31.v-04.vii.2017, 6ㅇ , 4.vii-26.viii.2017, 2 ㅇ and 26.viii-21.iv.2017, 1 q , Malaise

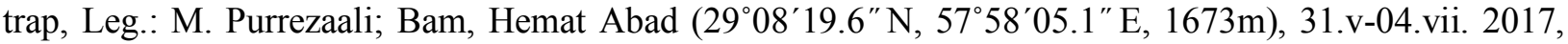
1'P', Malaise trap, Leg.: M. Purrezaali.

Distribution in Iran: Sistan and Baluchestan, Mazandran, Isfahan, Fars, Alborz, Guilan and Tehran provinces (Farahani et al., 2016).

General distribution: Palaearctic

\section{Aleiodes (Aleiodes) nocturnus Telenga 1941}

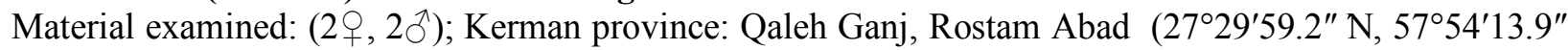
E, 387m), 10.iv-04.v.2017, 10َ, Malaise trap, Leg.: M. Ehsani; Manujan, Chah Nasri $\left(27^{\circ} 31^{\prime} 14.6^{\prime \prime} \mathrm{N}\right.$, 57 33'51.5" E, 384m), 10.iv-05.v.2017, 19 and 05-22.v.2017, 1ㅇ , Malaise trap, Leg.: M. Purrezaali; Manujan, Chermil $\left(27^{\circ} 31^{\prime} 14.6^{\prime \prime} \mathrm{N}, 57^{\circ} 33^{\prime} 51.5^{\prime \prime} \mathrm{E}, 445 \mathrm{~m}\right), 05-22 . v .2017,10^{\wedge}$, Malaise trap, Leg.: M. Purrezaali.

Distribution in Iran: Tehran and Guilan provinces (Farahani et al., 2016).

General distribution: Palaearctic

\section{Aleiodes (Chelonorhogas) apicalis (Brullé 1832)}

Material examined: (1 9$)$; Kerman province: Anbar Abad, Bardeh (28 $28^{\prime} 4.1^{\prime \prime}$ N, 58 $12^{\prime} 39.3^{\prime \prime}$ E, 1501m), 05.vi-05.vii.2017, 1 ㅇ , Malaise trap, Leg.: M.Purrezaali

Distribution in Iran: Sistan and Baluchestan, Isfahan, West Azarbaijan, Guilan and Mazandaran provinces (Farahani et al., 2016).

General distribution: Palaearctic

\section{DISCUSSION}

In the present research, we focused on the fauna of Braconidae of Kerman province, which has not been sufficiently explored until now. Totally 11 species in six genera belonging to three braconid subfamilies were identified and recorded from Kerman province, southeastern Iran. A single species, Opius (Cryptonastes) ficedus Papp, 1979 (Opiinae) was recorded for the first time for the fauna of Iran. Almost all the species identified in the current study were collected using Malaise traps, a single species, Chelonus annulipes, was collected using both sweep net (three specimens) and Malaise trap (a single specimen) . This species was collected from alfalfa fields (Medicago sativa) in Bidkhan, Negar and Dashtkar. Two species, Phanerotoma leucobasis and Xynobius rudis were collected using both Malaise trap (three specimens) and light trap (two specimens). Other species ( 85 specimens) were collected by Malaise traps. The geographical distribution of some species (Chelonus oculator, Phanerotoma permixtellae, Aleiodes bicolor, A. nocturnus and A. apicalis) is limited to the Palaearctic region, while other species are also distributed in other zoogeographical regions.

Prior to this study, the number of the recorded species of the three mentioned subfamilies in Kerman province were: 2 (Cheloninae), 19 (Opiinae) and 7 (Rogadinae) (Farahani et al. 2016; Ranjbar et al., 2016; Abdolalizadeh et al., 2017; Safahani et al., 2018). However, as a result of this study the number of known species of the first two subfamilies in Kerman province increased to 6 and 20 species respectively. There was no new record for Rogadinae.

In general, the wasps of the mentioned braconids are considered as the most important group of insects which have significant role in biological control of agricultural pests.

In conclusion, although the present study increases the number of species of Braconidae known from the province, but some habitats in north, northwestern and central parts of the province, have not yet been studied in detail and the real number is expected to be much higher. So more samplings are necessary to increase the knowledge of diversity and applicability of this important group of parasitoids in Kerman province.

\section{ACKNOWLEDGEMENTS}

This research was supported by Shahid Bahonar University of Kerman, Iran, which is greatly appreciated. Our special thanks are expressed to Miss M. Ehsani, Miss Sh. Mohebban and Mrs. F. Abdolalizadeh for 
helping us in sample collection. The authors are grateful to anonymous reviewers for their valuable comments and recommendations on the earlier version of this paper.

\section{REFERENCES}

Abdolalizadeh F., Madjdzadeh S.M., Farahani S. \& Askari Hesni M. 2017. A survey of braconid wasps (Hymenoptera: Braconidae: Euphorinae, Homolobinae, Macrocentrinae, Rogadinae) in Kerman province, southeastern Iran. Journal of Insect Biodiversity and Systematics, 3(1), 33-40.

Ameri A., Talebi A.A., Rakhshani E., Beyarslan A. \& Kamali K. 2014. Study of the genus Opius Wesmael (Hymenoptera: Braconidae: Opiinae) in Southern Iran, with eleven new records. Zootaxa, 3884(1), 1-26. http://doi.org/10.11646/zootaxa.3884.1.1

Belokoblyskij S.A. 1990. Review of Braconid wasps of the genus Rhaconotus Ruthe (Hymenoptera, Braconidae) of the Palearctic region. Entomological Review, 70, 47-67.

Coronado J. M., Ruiz E. \& Varela S.E. 2004. Adenda a Braconidae (Hymenoptera). In Llorente J.E., Morrone J.J., Yanez O. \& Vargas I. (eds.), Biodiversidad, Taxonomiay Biogeografia de Artropodos de México, 713-720. Hacia una Sintesis de su conocimiento. Conabio-Unam, Mexico.

Derafshan H.A., Rakhshani E., Farahani S. \& Peris_Felipo F.J. 2017. Adelius aridus (Tobias, 1967) (Hym., Braconidae, Cheloninae) associated with a Tamarix leafminer (Lepidoptera: Nepticulidae), new for Iran. Journal of Insect Biodiversity and Systematics, 3(3), 229-238.

Dolati S., Talebi A.A., Farahani S. \& Khayrandish M. 2018. New finding in Opiinae (Hymenoptera: Braconidae) from north of Iran. Journal of Insect Biodiversity and Systematics, 4(3), 163-182.

Dolati S., Talebi A.A., Farahani S. \& Khayrandish M. 2019. New Data of the Genus Opius Wesmael (Hymenoptera: Braconidae, Opiinae) from Northern Iran. Journal of Agricultural Science and Technology, 21(Suppl.), 18711887.

Farahani S., Talebi A.A., van Achterberg C. \& Rakhshani E. 2015. A review of the subfamily Rogadinae (Hymenoptera: Braconidae) from Iran. Zootaxa, 3973 (2), 227-250.

Farahani S., Talebi A.A. \& Rakhshani E. 2016. Iranian Braconidae (Insecta: Hymenoptera: Ichneumonoidea): diversity, distribution and host association. Journal of Insect Biodiversity and Systematics, 2(1), 1-92.

Fischer M. 1963. Eine neue Pectenopius-Art aus dem Iran (Hymenotera, Braconidae, Opiinae). Stuttgarter Beiträge zur Naturkunde, 98, 1-3.

Fischer M. 1971a. Hym. Braconidae, World Opiinae. In Delucchi V. \& Remaudičre G. (eds.), Index of Entomophagous Insects, 5, 1-189. Le François, Paris.

Fischer M. 1971b. Two Opius species imported from Uganda into Hawaii (Hymenoptera, Braconidae). Anzeiger für Schadlingskunde und Pflanzenschutz, 44,10-12.

Fischer M. 1972. Hymenoptera, Braconidae (Opiinae I). Das Tierreich, 91:1-620.

Fischer M. 1977. Hymenoptera: Braconidae (Opiinae II-Amerika). Das Tierreich, 96:1-1001.

Fischer M. 1987. Hymenoptera Opiinae III—aethiopische, orientalische, australische und ozeanische Region. Das Tierreich, 104:1-734.

Hedwig K. 1957. Ichneumoniden und Braconiden aus den Iran 1954 (Hymenoptera). Jahresheft des Vereins für Vaterläendische Naturkunde, 112(1), 103-117.

Khajeh N., Rakhshani E., Peris-Felipo F.J. \& Žikic V. 2014. Contributions to the Opiinae (Hymenoptera: Braconidae) of Eastern Iran with updated checklist of Iranian species. Zootaxa, 3784(2), 131-147. http://doi.org/10.11646/zootaxa.3784.2.3

Lashkari-Bod A., Rakhshani E., Talebi A.A., Lozan A. \& Žikić V. 2011. A contribution to the knowledge of Braconidae (Hym.: Ichneumonoidea) of Iran. Biharean Biologist, 5, 147-150.

Li X.Y., van Achterberg C. \& Tan J.C. 2013. Revision of the subfamily Opiinae (Hymenoptera, Braconidae) from Hunan (China), including thirty-six new species and two new genera. ZooKeys, 268: 1-168. https://doi.org/10.3897/zookeys.268.4071 
Mehrnejad M.R. 2009. Primary and secondary parasitoids of Kermania pistaciella Amsel (Lepidoptera: Tineidae: Hieroxestinae). II. Applied Entomology and Phytopathology, 76(2), 135-136.

Mehrnejad M.R. \& Basirat M. 2009. Parasitoid complex of the pistachio twig borer moth Kermania pistaciella Amsel (Lepidoptera: Tineidae), in Iran. Biocontrol Science and Technology, 5, 499-510.

Peris-Felipo F.J., Belokobylskij S.A. Derafshan H.A. \& Rakhshani E. 2018. Revision of the genus Hoplocrotaphus Telenga, 1950 (Hymenoptera, Braconidae, Opiinae). Journal of Hymenoptera Research, 62, 55-72. https://doi.org/10.3897/jhr.62.21858

Ranjbar M., Madjdzadeh S.M., Peris-Felipo F.J., Askari M. \& Rakhshani, E. 2016. A contribution to the fauna of Opiinae (Hym., Braconidae) of Kerman Province South- Eastern Iran. Journal of the Entomological Research Society, 18(1), 19-26.

Safahani S., Madjdzadeh S.M. \& Peris-Felipo F.J. 2018. Contribution to the fauna and phenological knowledge of high mountains Opiinae (Hymenoptera, Braconidae) in Kerman province (Iran). Journal of Insect Biodiversity and Systematics, 4(2), 73-83.

Shaw M.R. 1983. On evolution of endoparasitism: the biology of some genera of Rogadinae (Braconidae). Contributions of the American Entomological Institute 20, 307-328. Parasitoid Community Ecology. Oxford University Press, Oxford, 111-144.

Shaw M.R. 1997. Rearing parasitic Hymenoptera. Amateur Entomologist's Society, Vol. 25, Orpington, U.K. 47 p.

Shaw M.R. \& Huddleston T. 1991. Classification and biology of braconid wasps (Hymenoptera: Braconidae). Handbooks for the Identification of British Insects, $126 \mathrm{p}$.

Shenefelt R.D. 1975. Braconidae 8: Exothecinae, Rogadinae. In Vecht van. Der. \& Shenefelt R.D. (eds.), Hymenopterorum Catalogus (novo editio), 1115-1262. W. Junk B.V., The Hague.

Telenga N.A. 1941. Family Braconidae, subfamily Braconinae (continuation) and Sigalphinae. Fauna USSR, Hymenoptera, $466 \mathrm{p}$.

van Achterberg C. 2009. Can Townes type Malaise traps be improved some recent developments. Entomologische Berichten, 69(4), 129 -135.

van Achterberg C. \& Mehrnejad M.R. 2002. The braconid parasitoids (Hymenoptera: Braconidae) of Kermania pistaciella Amsel (Lepidoptera: Tineidae: Hieroxestinae) in Iran. Zoologische Mededelingen, 76 (2), 27-39.

Wharton R.A., Marsh P.M. \& Sharkey M.J. 1997. Manual of the New World Genera of the Family Braconidae (Hymenoptera). The International Society of Hymenopterists, $440 \mathrm{p}$.

Yu D.S., van Achterberg C. \& Horstmann K. 2016. World Ichneumonoidea 2016. Taxonomy, biology, morphology and distribution (Braconidae). Vancouver. Taxapad (Scientific names for information management) Interactive catalogue on DVD/CDROM. 